\title{
Money Demand and Economic Growth in Ethiopia
}

\author{
Mamo Esayas Ambe \\ Lecturer, Department of Economics, woliata sodo university, P.O.Box. 138
}

\begin{abstract}
In LDCs like Ethiopia, one of the major macroeconomic problems is the absence of effective monetary policy. The money demand function play a major role in macroeconomic analysis, especially in selecting appropriate monetary policy actions. The objective of monetary policy in the least developing countries (LDCs) is usually related to money and credit control, price stabilization and economic growth. Many LDCs considered, price stability as the most important objective of monetary polices and it is important to testing the stability of parameter of money demand function indicate the effectiveness of the conduct of monetary policy. The research to be conducted therefore is to investigate the determinants of money demand function. Based on the data, which could be found an error correction model (ECM) was applied to estimate the money demand function in Ethiopia. From the study it is found that, money demand is positively related with real GDP and it is negatively related with expected inflation. The coefficient of real effective exchange rate is positive or negative depending on the magnitude of the appreciation and depreciation of local currency. Thus the studies calls for appropriate formulation and implementation of sound monetary policy capable of bringing stability in the coomy coupled with sustainable growth.
\end{abstract}

Keywords : money demand, economic growth, error correction model

DOI: $10.7176 / \mathrm{DCS} / 9-1-02$

\subsection{Background of the study}

During the last decade of the $20^{\text {th }}$ century most of African countries south of Sahara started to implement economic liberalization measures and structural adjustment program (SAP). This changed situation has made empirical investigation of money demand to remain of interest to researchers.

Ethiopia is one of the sub-Saharan African countries which have embarked on structural adjustment program. The reform measures implemented so far have changed the prices of assets and this change might have affected the demand for cash balance. Furthermore, Ethiopia is developing economy with heavy dependence on external assistance. This situation makes the behavior of domestic agent to be strongly influenced by external economic and monetary development. This makes it appropriate to include a variable that measures changes in exchange rate.

Demand for many plays a major role in macro economic analysis especially in selecting appropriate monetary policy actions. Consequently a steady stream of theoretical and empirical research has bee carried out world wide over the past decades (Siram ,2005).

The presence of stable money demand function greatly facilitate the conduct of monetary policy as it tells policy makes have different variable are affected by change in the money supply ( Samuel,2005).

Estimating the money demand function for an economy has been a quest of many research endeavors since the beginning of the previous century. The special role that money plays in the economy has made it an important research topic.

The presence of money demand function enables policy makers to influence changed in important economic variable such as GDP, expected inflation and exchange rate.

\subsection{Statement of the Problem}

Ethiopia is one of the poorest countries in the world. The poor performance of the Ethiopian Economy has been largely attributed to distorted economic polices. Even though there is no consensus among the different schools of thought in economics on the role and effectiveness of macro economic polices, many developing countries introduce different macro-economic policy reforms in their economies following structural Adjustment program (SAP). To this end the country has launched a reform program to accelerate economic growth and development.

Monetary policy is one of the policy instrument employed to achieve rapid economic growth and stabilization. The objectives of monetary policy in the least developing countries (LDCs) are usually related to money and credit control, price stability and economic growth. Many LCDs consider price as the most important objective of monetary polices since they are supposed to suffer more from inflation then the Developed countries (DCs), and monetary polices are considered to be more effective than fiscal policies in dealing with inflation (Ghatak,1995).

In addition monetary polices are also regarded as useful for achieving equilibrium in the balance of payment and stabilize the exchange rates in LDCs. A country with a balance of payment surplus would reduce 
interest rate where as balance of payment deficit would raise the interest rate to encourage the inflow of funds. Such capital movement in the economy is supposed to bridge the balance of payments gap. Sodersten(1971) generalized this concept. "The monetary policy could be used to promote external balance where as fiscal policy could be used to promote internal balance and full employment."

Both theory and empirical studies seem to conclude that macro economic policies matter in influencing economic performance. One of the reason why the money demand function is widely researched is that demand for money lies at the "heart of macro economic polices," Fisher (1991) Money is linked to changes in economic variables that affect all of us and are important to the health of the economy. [Adam (1999) cited by Haile (2004)].

Moreover, testing the stability of parameters of the money demand function is important as it indicates the effectiveness of the conduct of monetary policy. This is because that the demand for money is a link between economic activities and monetary policy. As Deadman, (1995) showed one operational consequence of parameter instability in a demand for money equation is that predications about the effect of alterations in monetary policy would become more hazardous. Indeed such instability could in itself be a source of disturbance to the economy.

Stability of the money demand function that refers to constancy of the coefficient of its determinants and changes in variance of the money demand function are crucial to the studies of money demand.

Ethiopia has been undertaking a comprehensive economic reform program since October, 1992 after being ruled by centrally planning socialist regime for nearly two decades. In this regard, since the adoption of financial sector has undergone significant changes.

For instance, the exchange rate that was also fixed (pegged) before the reform period devalued significantly. These and other monetary policy variables, therefore, have their own impact on the money demand function previous rigorous study on the determinants and stability of money demand function in the case of Ethiopia is scanty. The purpose of this paper is therefore, to bridge this research gap investigating the determinants of the demand for real money balances, testing stability of the money demand function and proposing policy advises.

\subsection{Objectives of the Study}

In order to correct macro economic distortion and imbalance, Ethiopia like most of African countries, has accepted and been implementing a comprehensive economic reform program since 1992. The program as dictated by the financial programming model of the International monetary fund (IMF), which believe that macro economic imbalance in developing countries occur due to expansionary policy and if contractionary one or tight monetary and fiscal policies reveres this policy, imbalance could be corrected.

Hence, the attainment of targets of the program by the monetary authorities requires knowledge of the determinants and stability of the demand function. The general objective of the study is therefore; to formulate and estimate the money demand function in Ethiopian, in line with the above objective, the study is conducted with the following specific objectives

$>$ To see the stability of the money demand function

$>$ To examine the determinants of the money demand function

$>$ Based on the finding drawing some policy implications

\subsection{Significance of the Study}

As mentioned earlier, understanding the major determinants and getting stable money demand function play a significant role for monetary policy formulation. Therefore, the paper is significant in this respect by assessing the effectiveness of monetary policy. In addition it is significant by bridge the research gap that are not so far studied by previous research. For example (Zekarias 2004), to determine the money demand function in Ethiopia; He used only two variables such as GDP and expected inflation. However, this study differed by including the variable together such as GDP, expected inflation, real effective exchange rate and lagged real money balance. Finally it may also lead to identification of new problem for further investigation.

\subsection{Scope of the study}

This study limited only to estimating the broad money demand and looking for its determinants and stability. It therefore, mainly focuses on determining the determinants of the demand for money in the Ethiopian economy using time series econometric model. The coverage time span of the research will be from 1971/72 to 2008/2009.

\subsection{Research Hypothesis}

The researcher wants to test the following hypothesis

1. The demand for money is influenced by the amount of Gross domestic product, expected inflation and real effective exchange rate.

2. There is a stable relation ship between a broad money and gross domestic product, expected inflation 
and real effective exchange rate.

\subsection{Data and Methodology}

Secondary data obtained from National Bank of Ethiopia, and Ministry of Finance and Economic Development (MoFED). Categories of information, annual data series of before 1992 and after 1992 have been utilized for empirical analysis. Based on the data, which could be found, an error correction model (ECM) will be applied to estimate the money demand function in Ethiopia.

\section{CHAPTER TWO \\ MODEL SPECIFICATION, DATA, METHODOLOGY, ESTIMATION TECHNIQUE AND RESULTS 2.1 Model specification}

Conventional money demand theory suggests that behaviour of money demand function is determined by scale and opportunity cost variables. This standard equation approach to the estimation of a demand for money function for a less developed country (LDCs) has been familiarized by (Gujarati 1968, as cited in Ghatak, 1995).

According to his estimation, real demand for money is assumed to be function of real income, real interest rate and inflation uncertainty. These could be categorized as scale variables, which related to measures of economic activities like income, expenditure or wealth, while the others as opportunity cost variables. These include variables such as both domestic and foreign interest rates, expected inflation, expected exchange rate (currency substitution) and the price level.

Generally the functional relationship of the money demand function represented by as equation below

$$
\mathbf{M} / \mathbf{p}=\mathbf{f}(\mathbf{Y}, \mathbf{R})
$$

Where, $\mathrm{M} / \mathrm{P}$ is the desired real money balances

$\mathrm{Y}$ is to represent the economic activity

$\mathrm{R}$ is the opportunity cost of holding money

$\mathrm{M}$ is stands for selected monetary aggregates in nominal terms

$\mathrm{P}$ is the price

We take the nominal money supply to represent the money demand because in the long run, it is assumed that the money market in equilibrium and then the money $\operatorname{supply}\left(\mathrm{M}_{2}\right)$ deflated by the price level $(\mathrm{p})$ is equal to the real demand for money $\left(\mathrm{M}_{\mathrm{d}} / \mathrm{p}\right)$. Such an approach was used by Elbadawi(1981) and Mathews (1996) Both of these works estimate the stable long run real money demand equation

To this end, the long run real money demand function for Ethiopia can be better modeled as a specification of the following forms.

$$
\underline{M d}=F\left(\text { GDP, } P_{e}, \text { REER, } M_{d} / p-1\right)
$$

Where $M_{d}$ is the stock of money, $M_{d} / p$ is real money demand, $P_{e}$ is expected inflation, REER is real effective exchange rate and $\mathrm{M}_{\mathrm{d}} / \mathrm{p}$-1 is the previous year real money balance.

Following a common formulation of money demand we specify the long run real money demand unction in logarithmic forms as

$$
\begin{aligned}
& \text { LRM2 }=\beta_{0}+\beta_{1} \text { LRGDP }+\beta_{2} P_{e}+\beta_{3} \text { LREER }+\beta_{4} L\left(M_{d} / p-1\right)+\varepsilon \\
& \text { Where, LRM2 }=\log (\mathrm{M} 2 / \mathrm{p}) \\
& \text { LRGDP } \quad=\log (\text { real gross domestic Product) } \\
& \mathrm{LP}_{\mathrm{e}} \quad=\mathrm{Log} \text { (expected inflation) } \\
& \text { LREER }=\text { Log (real effective exchange rate) } \\
& \mathrm{L}\left(\mathrm{M}_{\mathrm{d}} / \mathrm{p}-1\right) \quad=\mathrm{Log} \text { (lagged real money balance) } \\
& \mathrm{E}=\text { Error term }
\end{aligned}
$$

\subsection{Explanation of the variable}

\subsubsection{The dependent variable}

The money balances taken in the study is broad money supply which is sum of narrow money (Currency circulation plus demand deposit) plus quasi money( Saving and time deposits). Although Sirram (1999), cited in Fofanah,(2004) in his empirical survey indicated that narrowly defined monetary aggregates is a better aggregate for policy formation in LDCS, there is also equally important argument in the appropriateness of broad definition of money $\left(\mathrm{M}_{2}\right)$ for developing countries. In the words of Jenkins (1999) broad money is both an asset that can be used for transaction purposes and on asset that transaction purposes and on alternative store of value yielding interest income. Thus demand for money is the demand for real balances. This is based on the assumption that the price elasticity of nominal money balance is unity (Boorman,1980). The implication of this is that individuals do not suffer from money illusion.

2.2.2 The Explanatory variable

The inclusion of income or any other variable that measures the volume of transaction emanates from role of money as a medium of transaction. The use of such a variable is well documented in the works of Keynes, the 
Cambridge school and Baumol Tobin's inventory theoretic model of money demand. In all these works it is shown that when real income rises, individuals demand for money increase. Thus current real income has been viewed as one of the determinants of the demand for real balance. Friedman on the other hand suggested the use of "permanent income" in money demand function as a proxy for wealth which shows the volume of transaction.

Money is only one of the assets that are available to the public. That is there are other assets that can yield a real rate of return. Thus when individuals decide to hold money they forgo the return they could obtain by holding other assets. In effect, the holding of money has an opportunity cost. Hence, the demand for money is determined, among other things, by this opportunity cost specifically, if the opportunity cost rises, people change their portfolio composition and reduce their demand for money. Thus the demand for money is negatively related to the opportunity cost variable.

In the money demand literature interest rate is used as the opportunity cost variable Laidler (993). The choice of interest rate as opportunity cost variable is not disputed in the context of developed economies which have well functioning financial markets. In fact most empirical studies of money demand in developed countries use interest rate as the opportunity cost variable (Miller, 1991).

However, the literature on money demand in developing countries stresses that the expected rate of inflation rather than the interest rate should be used as a proxy for the opportunity cost of holding real balances (Domowitz and Elbanawi,1987).

Gemech (1993) This is based on the fact that in most developing countries financial markets are nonexistent or even if they exist, they are underdeveloped. Moreover, in these countries interest rates are administratively set. Thus interest rate do not reflect the true opportunity cost of holding money and individuals do not change the composition of their portfolio in response to movement in interest rates. In effect the alternative assets that are available to the public are real assets whose yield depends on the rate of inflation. This is because people hold their assets in the form of real goods (such as consumer and producer durables) since their prices generally rise with the general price level specifically, as expected inflation rises individuals reduce their holding of money balance and increase real asset hooding in their portfolio. In general, previous studies of money demand in developing economies pointed to the importance of the substitution effects between real assets and real money balances. It is argued that in developing countries where financial market are non-existent or underdeveloped the appropriate opportunity cost variable in the money demand function should be the expected inflation rate and not the interest rate Ghatak (1995). Consequently, many empirical studies of money demand in developing countries have ignored interest rates from their money demand equations.

Ethiopia is one of the developing countries where financial market are non-existent. Hence interest rate has no role as opportunity cost variable and is exclude from our money demand model. Instead we introduce the expected rate of inflation as the opportunity cost variable in the money demand function. Following simmon (1992), Gemech (1993), and mathews (1996) we use actual and lagged inflation value as proxy for expected inflation.

The other price variable used in the model specification is the real Effective exchange Rate (REER), which is the multilateral real effective exchange rate of the domestic currency relative to its partner countries. The real effective exchange rate is generally taken as a proxy for the competitiveness of countries in the international market. Nominal depreciation or appreciation of the domestic currency doesn't necessarily lead to real depreciation or appreciation that is why we take real effective exchange rate rather than nominal effective exchange rate. As theoretically expected, devaluation by raising the price of both exportable and importable on domestic currency, which encourages exports and discourage imports which is one of the determinants of money supply and money demand Ghatak (1995). It is defined in terms of domestic currency per unit of foreign currency so that an increase in REER is a relatively real effective depreciation.

The formula is

Where

$$
\text { REER }=\mathbf{t} \quad \sum_{\mathrm{J}=1}^{\mathrm{K}} \mathbf{W j t} \mathbf{e}_{\mathrm{it}} \quad \underline{\mathbf{P t}^{*} / \mathbf{p}_{\mathbf{t}}}
$$

$\mathrm{REER}=$ the real effective exchange rate of the home country of time $\mathrm{t}$.

$\mathrm{Wjt}=$ the trade weight of domestic country attached to partner $\mathrm{j}$ at time $\mathrm{t}$.

eit $=$ nominal exchange rate of the home country in terms of its currency per unit of the currency of country $j$ at time $\mathrm{t}$.

$\mathrm{Pt}^{*}=$ whole sale price index of the partner country of time $\mathrm{t}$.

$\mathrm{Pt}=$ consumer price index of the home country at time $\mathrm{t}$

\subsection{The Data Sources}

The data for this study were obtained from various Sources. The main sources are National Bank of Ethiopia (NBE), Central Statistical Authority (CSA), and Ministry of Economic Development and Cooperation (MEDAC). The data used in this study were annual data from 1971/72 to 2008/09. 
The data on monetary aggregates, inflation and GDP are obtained from NBE and Ministry of Economic Development and Cooperation (MEDAC), respectively. The data for real effective exchange rate (REER) is also obtained from NBE.

\subsection{Estimation Result and Analysis}

2.4.1 Time series characteristics of the data

As we have seen in section 2.1 before estimating the ordinary least square regression of time series variable; it is a mandatory to check their stationary. And if it found to be non-stationary, need to be transformed in some way before model are estimated. In this connection, Ghatak (1995) state the most economic variable first differencing is sufficient to achieve stationary. And the variables are described as being integrated of order one or I (1).

Considering the above premises, the Augmented Dickey-Fuller (ADF) unit root test were under taken to verify whether the variable in our money demand function are stationary and the result of data are presented in table below.

Table 2.1 ADF statistics for testing unit root

\begin{tabular}{|c|c|c|c|c|c|c|}
\hline & \multicolumn{6}{|c|}{ Dick fuller class test } \\
\hline & \multicolumn{2}{|c|}{ Dick Fuller } & \multicolumn{2}{|c|}{ Augmented Dicky Fuller } & \multirow{2}{*}{\multicolumn{2}{|c|}{ Lag length 2}} \\
\hline & \multicolumn{2}{|c|}{ Lag length o } & \multicolumn{2}{|c|}{ Lag length 1} & & \\
\hline & Constant & Constant and trend & Constant & Constant and trend & Constant & Constant and trend \\
\hline DLM & $-4.155^{* *}$ & $-4.034 * *$ & $-3.097 * *$ & $-2.981 *$ & -2.561 & -2.74 \\
\hline DLRGDP & $-8.049 * *$ & $-8.245 * *$ & $-3.843 * *$ & $-4.005 * *$ & $-3.140^{*}$ & $-3.340 *$ \\
\hline DLPe & $-10.95 * *$ & $-10.78 * *$ & $-6.630 * *$ & $-6.529 * *$ & $-4.596 * *$ & $-4.520 * *$ \\
\hline DLREER & $-3.845 * *$ & $-3.767 * *$ & $-3.379 *$ & -3.2968 & -2.904 & -2.804 \\
\hline DLLagM & $-5.073 * *$ & $-5.368 * *$ & $-4.078 * *$ & $-4.399 * *$ & $-3.405^{*}$ & $-3.743 * *$ \\
\hline
\end{tabular}

$*$ and $^{* *}$ refers to significance level at $1 \%$ and $5 \%$ or $99 \%$ and $95 \%$ confidence interval respectively.

The null hypothesis (Ho) is that $\alpha=0$; that is there is a unit root. Thus the time series is non- stationary. The alternative hypothesis is that less than zero that the time series is stationary. This test has conducted for each variable first at level and then in their first difference. The test conducted with the variable in level indicates that no variable are stationary except for some.

\subsection{The Long Run Money Demand Model}

The estimation of the long run model reveals that real GDP and lagged real money balance are positive determinates of the demand for real money demand while expected inflation and Real Effective exchange rate is found negatively related with demand for real money balance .The parameter for all variable have the expected sign in line to economic theory. In addition, the test of significance shows that real GDP and lagged real money balance are significant at $5 \%$ level of significance.

However, the ADF statics result for stationary indicates on all the variables, the null hypothesis of the existence of unit root is rejected when a trend tem is included. This indicates that including the trend term improves the stochastic nature of the data. Thus we can conclude that all the variables are integrated of order one i.e. $\mathrm{I}(1)$.

After we have shown that all the variables in the money demand function are I(1). The next procedure is checking whether there is a meaningful long run relation ship between the money demand variables. As Granger (1986) cited in Gujarati,(2003) note. "A test for co-integration can be thought of as a pre-test to avoid 'spurious regression' situations."

Thus the concept of integration implies that even if variable in regression are not stationary, their linear combination may be stationary that is the variable have long run relation ship.

After checking the order of integration and estimating the long run model. In this section, co integration techniques are mode by following the Engle and Grangr (1997) procedures. To examine the variable to be co integrated this is in essence, testing for the stationary of residual.

What we specifically do here is checking whether the error term generated using the regression on the variables is stationary or $\mathrm{I}(0)$ otherwise not stationary. This is by estimating the equation with the long run money demand model. The residual is saved and tested for stationary. Table show the ADF test of the test of the residual.

The error term is stationary at level at $5 \%$ level of significance since negative, significant computed ADF-t values reject the hypothesis of a unit root in series of a residual. This implies that the series of residual term is stationary or $1(0)$

Thus we can say that the variable used in our money demand function is co integrated.

On the other hand, the multivariate system diagnostic test of the residuals (shown in the lower block of Table 4.2) indicates that the model has the desirable property of OLS estimation. Test for serial correlation (AR Test) which is used to check whether the error terms are correlated to each other or not, indicate non-existence of 
serial correlation in the real money demand function. The result of hetroscedastic test (ARCH TEST) of the residual also does not show evidence for autoregressive conditional hetrosecastic error which if present would result in biased variance of estimation and would also be mode the least square estimates inefficient(Green,1997).

The jargu-Bera test of skew ness and kurtosis of the residuals revealed normality implying the absence of outliers in the data. The Ramsay's regression specification error test (RESET), On the other hand, provides no indication that the function form of long run model is in appropriate.

Table 2.2 Long run estimation result

\begin{tabular}{|c|c|c|c|c|c|}
\hline & Coefficient & Std.Error & t-value & t-prob & Part.R^2 \\
\hline Constant & -0.331851 & 0.4865 & -0.682 & 0.500 & 0.0148 \\
\hline LRGDP_1 & 0.682216 & 0.05744 & 2.48 & 0.009 & 0.1651 \\
\hline LPe & -0.0277396 & 0.01071 & -2.59 & 0.014 & 0.1780 \\
\hline LREER & -0.0724149 & 0.04092 & -1.77 & 0.087 & 0.0918 \\
\hline LLag M & 0.760732 & 0.08264 & 9.21 & 0.000 & 0.7322 \\
\hline sigma & \multicolumn{2}{|l|}{0.0685249} & RSS & \multicolumn{2}{|l|}{0.145565349} \\
\hline $\mathbf{R}^{\wedge} \mathbf{2}$ & \multicolumn{2}{|l|}{0.989027} & $F(4,31)=$ & \multicolumn{2}{|l|}{$698.5[0.000] * *$} \\
\hline log-likelihood & \multicolumn{2}{|l|}{48.1099} & DW & \multicolumn{2}{|l|}{1.67} \\
\hline no. of observa & \multicolumn{2}{|l|}{36} & \multicolumn{2}{|c|}{ no. of parameters } & 5 \\
\hline mean $(\mathrm{LM})$ & \multicolumn{2}{|l|}{2.60182} & $\operatorname{var}(\mathbf{L M})$ & \multicolumn{2}{|l|}{$\mathbf{0 . 3 6 8 4 9 5}$} \\
\hline \multirow{2}{*}{\multicolumn{6}{|c|}{$\begin{array}{l}\text { AR 1-2 test: } \quad F(2,29)=0.30201[0.7416] \\
\text { ARCH 1-1 test: } \quad F(1,29)=0.063135[0.8034]\end{array}$}} \\
\hline & & & & & \\
\hline \multicolumn{6}{|c|}{ Normality test: $\mathrm{Chi}^{\wedge} 2(2)=0.35504[0.8373]$} \\
\hline \multicolumn{6}{|c|}{ hetero test: $\quad F(8,22)=0.83988[0.5783]$} \\
\hline \multicolumn{6}{|c|}{ hetero-X test: $\quad F(14,16)=0.74772[0.7048]$} \\
\hline \multicolumn{6}{|c|}{ RESET test: $\quad F(1,30)=0.68023[0.4160]$} \\
\hline
\end{tabular}

2.5.1 The short run Dynamic Error Correction Model

After co-integration analysis and finding a significant error correction term, we proceed to modeling the dynamic demand equation with different diagnostic test. This dynamic specification helps us to analyze the behavior of economic agents out of equilibrium because in the long run or statistic behavior of the demand for real balances does not provide insight in the behavior of agents out of the equilibrium.

After we have checked the variables are being co-integrated, here is an error correction model (ECM) representation of this variable. In this connection Ericcsson (1998) as cited on Fofana (2004), explain ECM is an encompassing model and the partial adjustment model and appears to be suitable for money demand analysis even under adverse conditions.

Based on the above result, the variables included in the dynamic short run model such as real GDP, expected inflation and lagged real money balance are significant.But real effective exchange rate are insignificant. The short run model shows that error correction term(ECM-1) is found to be statistically significant and have expected sign. The results shows that in the presence of an unanticipated monetary equilibrium, the speed of adjustment for real broad money is annually, as agents adjust to their desire long run path. The coefficient of determination $\left(\mathrm{R}^{2}\right)$, indicates that $52.9 \%$ of the demand for real money balance is explained by the variable included in the regression.

The overall significance, F-test, established shows that the explanatory variable jointly explains the demand for real money significantly which is different from zero at significant level. 
Table 4.3 Short run estimation result

\begin{tabular}{|c|c|c|c|c|}
\hline Coefficient & Std.Error & t-value & t-prob & Part.R^2 \\
\hline-0.0282008 & 0.02163 & -1.30 & 0.203 & 0.0554 \\
\hline DLRGDP_1 & 0.1662 & 2.56 & 0.016 & 0.1840 \\
\hline-0.0224897 & 0.007245 & -3.10 & 0.004 & 0.2494 \\
\hline-0.0184035 & 0.06697 & -1.92 & 0.123 & 0.2066 \\
\hline DLLag M & 0.2129 & 3.63 & 0.001 & 0.3128 \\
\hline-0.744102 & 0.2646 & -2.81 & 0.009 & 0.2142 \\
\hline 0.0601883 & \multirow{2}{*}{\multicolumn{2}{|c|}{$\begin{array}{c}\text { RSS } \\
\mathbf{F}(5,29)\end{array}$}} & 56395 & \\
\hline 0.529998 & & & $0.0001 * *$ & \\
\hline log-likelihood $\quad 51.9878$ & \multicolumn{2}{|c|}{ DW } & .73 & \\
\hline no. of observations 35 & \multicolumn{2}{|c|}{ no. of parameters } & 6 & \\
\hline mean(DLM) & \multicolumn{2}{|c|}{$\operatorname{var}(\mathrm{DLM})$} & 38638 & \\
\hline \multicolumn{5}{|l|}{ AR 1-2 test: $\quad F(2,27)=0.54418[0.5866]$} \\
\hline \multicolumn{5}{|l|}{ ARCH 1-1 test: $\quad F(1,27)=0.15342[0.6984]$} \\
\hline \multicolumn{5}{|l|}{ Normality test: $\mathrm{Chi}^{\wedge} 2(2)=0.17876[0.9145]$} \\
\hline \multicolumn{5}{|l|}{ hetero test: $\quad F(10,18)=0.43670[0.9089]$} \\
\hline \multicolumn{5}{|l|}{ Not enough observations for hetero-X test } \\
\hline$F(1,28)=0.34710[0.5605]$ & & & & \\
\hline
\end{tabular}

\subsection{Economic Interpretation of the parameters}

As mentioned in the previous section, the real GDP, expected inflation and lagged real money balance are significant in both long run and short. However Real effective exchange rate are significant in the long run but insignificant in the short run.

The performance of the economy as can be represented by the country gross output is positively related to real money balance. This is both for the long run and short run. This because in the works of Keynes, the Cambridge school and baumo-Tobin inventory the theoretic model of money demand it is show that when real income rises, individual demand for money increase. Therefore, what can be conclude from the result is that good performance of the economy has increase the demand for real money balances.

The lagged inflation values as a proxy for expected inflation has a negative effect in the long and short run. This result is similar to that of Ergette(1998) and streken (1999). The negative sign of expected inflation is as the result of economic agents preferring to hedge against inflation of expected higher inflation. But it is also possible that expected inflation to have a positive effect on money demand. As agents expect prices to rise they could simply increase their money holing to match the expected rise in nominal expenditure ( Sirram,1999).

The impact of real effective exchange rate on the real money demand is negative in the long run and shot run. But it is found that it has insignificant effect in our short run broad money demand. This similar to the finding Gemech (1993) and Arise et al (2000), but contrast to that of Civeir (2003). The negative sign of real effective exchange rate shows deprecation of the real exchange rate and real money demand balance through its negative impact of current account to the open economy in the long run which contradicts one of her IMF prescription of LDCs for balance of payment improvement by encouraging export and discouraging import after devaluation.

The lagged real money balance has positive effect in the long and short run. The result is similar to the Fofahng (2001) and Zakarias (2002). It has positive effect because much of the under review period the demand for real money balance shows that increasing trend. Therefore we can conclude that the previous year demand for real money has positive effect on the current real money demand.

Finally, the negative sign of ECM-1 shows that if any period, the amount of money balances were above equilibrium level, the holder will reduce his demand in the next period (in our case a year). Specifically, a fall in excess money in the last period will result in a higher level of desired money balances in the current period. That is, it essential for maintaining long run equilibrium to reduce the existing dis-equilibrium overtime.

\section{CHAPTER THREE}

\section{Conclusion and Policy Implication}

\subsection{Conclusion}

These studies tried to find that the real money demand is affected by different factor and monetary policies variable like the real GDP of the country, the expected inflation, Real effective exchange rate and lagged real money balance. 
Monetary development is usually explained by growth in domestic liquidity, excess reserve of commercial banks, deposit mobilization and development in monetary aggregates. To this effect it has attempt to explain growth in money supply and development in deposit mobilization of the banking system as indicators of monetary development and it has attempted to examine the factors that determine the demand for money in Ethiopia.

In empirical analysis, money demand model is estimated for broad definition of money. Conventional money demand function has been estimated by using time series data by the Engle and Granger (1987) two stage procedures, a specification which uses the econometrics theories of error correction and co integration to determine the long run relationship and the dynamic structure of the money demand function.

In formulating the money demand function, the study include real GDP, expected inflation, Real effective exchange rate and lagged real money balance that affect both the demand and supply of money and the monetary development of the country. The time series characteristics of the above variables have been established using Augmented Dickey-fuller (ADF) test and young that all variable are integrated of order one of I (1).

The estimation of the model revealed that real GDP and the lagged real money balance are positively related with the demand for money both in the long run and short run. Expected inflation and real effective exchange rate are the variable that affects the demand for money negatively in the long run and short run. The negative sign of real effective exchange rate shows deprecation of the real exchange rate and real money demand balance through its negative impact of current account to the open economy in the long run which contradicts one of her IMF prescription of LDCs for balance of payment improvement by encouraging export and discouraging import after devaluation.

In the short run, the error correction model indicated that the real GDP, expected inflation, lagged real money balance and lagged error term variables are important for error correction of monetary adjustment. The role of real effective exchange rate is statistically insignificant implying weaker impact of monetary policy on the balance of payment either positively or negatively in the short run.

The coefficient of error correction term is with the expected sigh and significant, estimated around 0.529. The size of the coefficient suggests that about 52.9 percent of the shock of the real money will adjust torward the long run path during the year.

In spite of the comprehensive reform program, and changes in macro economic policies, the empirical result of stability test show that money demand function is stable over the study period (1972 to 2009 E.C ). The techniques employed to test stability is chow's breakpoint test revealed that money demand equation is stable. This implies that the money demand function can be used for policy purpose.

\subsection{Policy implication}

$>$ The policy implication of this result is that in conducting monetary policy, income (GDP), expected inflation, real effective exchange rate and lagged real money balance should be considered in the long run. However, exchange rate variable are not important in determining the behavior of the money demand function in the short run.

$>$ Despite the fact that the depreciation of the REER index since 1998/99 should have helped to improve the competitiveness of Ethiopia's exports in the international market, the latter has been deteriorating. This shows that market discrepancy between the neoclassical prediction and the reality in Ethiopia. This because conventional economics fail to take in to account the peculiar characteristics of LDCs economies that is which we found a negative relation ship between real money demand and also its important on real money demand is negligible in the short run.

$>$ The other findings of this paper are that the rate of inflation plays a significant role in shaping the short run behavior of agents. Hence the authorities have been targeting inflation to ensure macroeconomic stability. The authorities have been targeting inflation to a single digit rate.

$>$ The growth in the saving deposit indicated in the discussion part has resulted in the accumulation of excess liquidity in bank. A rising lending rate carries the possibility of crowding out private investors even if it not deliberates. This is so because the crowding out of the private sector can be either direct or indirect. Therefore the government should be to reduce both deposit rate and the lending rate.

$>$ Stability of the money demand equation seem to suggest that indirect monetary policy like open market operation would imply that the demand for money function estimated in one period would be predict well in another period.

$>$ Consequently, the government should give more emphasis in promoting various investment activities by avoiding or minimizing the problem on the real sector. This include a package of policy measures includes the provision of adequate infrastructure, bank credit facilities and constantly keeping the real exchange rate in line with international development so as to make the external sector more competitive in the international market. 


\section{Reference}

$>$ Adam C. (1999) "Financial Reform And Currency Demand In Zambia Journal Of African Economies Vol .6 No 3 .

$>$ Aango And Nadir (1982) Strategies For Financial Reform Interest Rate Policies Stabilization And Bank Supervision In Developing Countries.

$>$ Arize, Maidletos And Shwitt (1999), Profit Possibilities In Currency Market Arbitrage, Medging And Speculation. The Financial Review.

$>$ Attingi-Ego, M And Kent Matew (1996) Demand For Narrow And Broad Money In Uganda ," African Review Of Money Finance And Banking No 1.2

$>$ Bain And Howells (2003). The Demand For Money In Iran Journal Of Macroeconomics.

$>$ Bofinger Peter (2002) Monetary Policy, Goals, Institutions, Strategies And Instruments. Oxford University Press. New York.

$>$ Befekadu (2001) Annual Report On Ethiopian Economy Vol.I Addis Ababa,Ethiopia.

$>$ Civeri Iirfan (2003). Broad Money Demand And Currency Substitution In Turkey. The Journal of Developing Areas Vol.36 No. 2 Ankara University, Faculty of Political Science.

$>$ Dead Man D. F (1995) The Demand For Money In LDCs Empirical Result In Ghatak Edition Monetary Economics In Developing Countries.

$>$ Domowitz And Elbadawi (1987). An Error Correction Approach To Money Demand .The Case Of Sudan Journal Of Development Economics

$>$ Elbadawi .S (1981) Income Velocity Of Money In Agricultureal / Developing Economies, Review Of Economics And Statistics.

$>$ Ergete Assefa (1998) An Error Correction Approach To Money Demand. The Case Of Ethiopia MSC Thesis ,AAU 